摘録

\section{採 鉱・採，炭}

\section{7）ノール・パ・ド・カレー炭田ドゥアイ区 におけるロープソー採炭の経験}

R. Joux: Une expérience de scie à câbles au Groupe de Douai des Houillères du Nord-Pas-de-Calais (Revue de l'Industrie Minérale Vol. 47, No. 2 (féurier 1965) p. 157 169)

ドゥアイ区では, その稼行炭層の $55 \%$ 以上が $35^{\circ}$ 以上 の急傾斜で，平均山タケは $1 \mathrm{~m}$ を少し越える程度であ る。パネルの垂直間隔を $50 \mathrm{~m}$ 前後に括いて採掘しようと しても, シュウ曲や断層が多いため，それにも打のずか ら制約がある。このため，長壁式といつても非能率的な 方式のままに扣かれたし，その㴗かに，柱房式採炭法を 部分的に取り入れたりなどした。したがつてこれらの O.M.S.は，わずかに 3〜 4t を維持するのが精一杯であ つた。これをなんとか機械化しようとして，幾つかの採 炭機械を入れてみたが，層の条件が適しないのと，落盤 などのために，とてもそれらの応用がむずかしいことを 認めざるを得なかつた。次にはチェンスクレーパを入れ てみた。これは良い結果をもたらし，従来よりも O.M. S.が50\%増加するこそになつた。それでも 4 5tがせい ぜいであり，本問題をいつきよに解決する方策として， 最近ソ連でかなりの成功を見ているロープソー採炭の導 入を思い立ち，セスバール炭鉱 (le siège de Sessevalle)でその利用試験を行なつてみた。その結果は非常に 良好で，使いなれるのにす早く，今まで 8 カ月の初期的 試験の成績だけで充分に力づけられた。

本試験は同鉱 No. 2 層に対して行なつたもので，パネ ルの垂直間隔は $50 \mathrm{~m}$ のま, 炭層の山タケは $0.60 \mathrm{~m}$, 傾 斜が 50 ～ $60^{\circ}$ である。石炭の堅さのバラッキがひどく， 上・下艋はフランス北部に特有の砂岩でできている。

パネルホールの作孔には Binaut 型複式ボーリングマシンを用いた。 これは直径 $400 \mathrm{~mm}$ の回転ビットを 横に 2 本並べたもので, 互いに逆回 転を行ない, $800 \mathrm{~mm} \times 400 \mathrm{~mm}$ のボ アホールをつくることができる。炭 層の起伏にあわせて行くだけの，適 度の届曲性も備えている。平均して 1 日に約 $60 \mathrm{~m}$ の作孔実績を示し，こ れに 8 工数を要する。同機の本体価 格が90,000フラン(1フランう73円)で， 作孔長さ $70 \mathrm{~m}$ ぶんの付属装置を含め ても 160,000 フランでめるため，作 孔長さ $1 \mathrm{~m}$ 当りの原価は 20 フランて いどと考えることができる。

採掘炭柱の幅が $5 \sim 6 \mathrm{~m}$ 以下でめ る場合と；それ以上の場合とに分けて，払フケの構造を 第27・1図のように準備する。これにはピックハンマを使 用した。

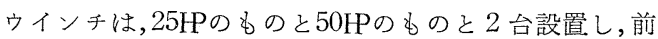
者は直径 $16 \mathrm{~mm}$ のロープを使用する時，後者は $22 \mathrm{~mm}$ の ロープの場合に用いる。25Hウインチではピック 8 個を 取り付け，これに長さ $0.30 \mathrm{~m}$ のスリーブを用意する。 50 Pウインチでは，ピックが 12 個，スリーブ長さが $0.40 \mathrm{~m}$
になる。スリーブ間隔は，採掘炭柱の幅に応じて，短い ので $0.70 \mathrm{~m}$ ，長くて $1.25 \mathrm{~m}$ の間で調節する。滑車の直径 も，16mmのロープには $250 \mathrm{~mm}, 22 \mathrm{~mm}$ ロープには350 $\mathrm{mm}$ ，できれば $550 \mathrm{~mm}$ とした。

ロープソー採炭における技術面の重要な課題のひとつ は天盤管理である。これは天盤の安定性によつて違うこ とではあるが，払跡のバレが切削工程の妨げにならない ような仕操の選定が要求される。本鉱では，(1) 間にパ ネルホールを置くだけの連続炭柱方式，(2) 残柱を付設 する方式，(3) 大きなパネルホールをつくつてこれに支 保を施こす方式, 以上の 3 方式について比較試験を行な つた。(2) 方式については残柱幅; ソーの通過幅扣よび ブロック炭柱数の組合せを 3 通りに変えた。このうち第 1 の組合せが同層の天盤状況に最も適していることが認 められた。第 2 の組合せは，天盤の状況があまり良くな い所に対して行なつたもので，やはりかなりの採掘時バ レが認められた。第 3 の組合せもこれに似ている。

採掘炭柱の回転率を良くするために, ソ一の通過幅 10 $\mathrm{m}$ を $6 \mathrm{~m}$ と $4 \mathrm{~m}$ との 2 つに分けて採掘したが，初めの $6 \mathrm{~m}$. の採掘炭柱の採掘も，それほどむずかしくはなかつた。

第 3 方式では，パネルホールを卸向きに $1.50 \mathrm{~m}$ をでピ ックで掘りひろげ，これに支保を施こす。本方式は，残: 炭柱をなくし，採収率を高めることを目的としたもの で, 初めに 10 12m の幅の採掘炭柱にし, 抎大ホール. に金網付き支保を行なう。

これら 3 方式についてその試験結果を表示したのが第 27・1表である。

この資料にもとづいて, その後の採炭方式の設計を行 ならことになつたが，残柱率5\%はやむを得ないことで， ロープ切削時に打ける採掘口スに大きな違いのあること も明らかである。

炭ジン対策としては, 稼行中の採掘炭柱とウインチと

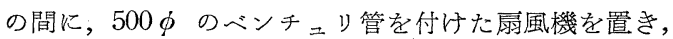
坑内気流のリサイクルを行なわせている。さらにフケ䁚 第27・1表 パネル内採風炭柱の特㱟とその結果

\begin{tabular}{|c|c|c|c|c|c|c|c|c|c|c|c|c|}
\hline \multicolumn{6}{|c|}{ ロープソ一採孷規格 } & \multicolumn{7}{|c|}{ 実 } \\
\hline 1 & \multicolumn{3}{|c|}{2} & \multirow{3}{*}{ 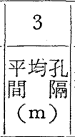 } & \multirow{3}{*}{$\mid \begin{array}{c}\frac{4}{\text { ln }_{\text {柱率 }}} \\
(\%)\end{array}$} & \multirow{3}{*}{$\frac{5}{\text { 採掘炭 }}$} & \multicolumn{2}{|r|}{6} & \multirow{2}{*}{ 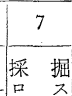 } & \multirow{2}{*}{$\left|\frac{8}{\mid}\right|$} & \multirow{2}{*}{\multicolumn{2}{|c|}{$\frac{9}{\text { 直接夫能率 }}$}} \\
\hline \multirow{2}{*}{ 方 } & \multirow{2}{*}{\multicolumn{2}{|c|}{ 形 }} & \multirow[t]{2}{*}{ 状 } & & & & \multicolumn{2}{|c|}{ 採崖 量 } & & & & \\
\hline & & & & & & & $\mathrm{t}$ & $\%$ & $(\%)^{2}$ & $\mid(\%)$ & \multicolumn{2}{|c|}{\begin{tabular}{l|l}
$\mathrm{m}^{2}$ & $\mathrm{t}$
\end{tabular}} \\
\hline 連. 続 炭 柱 & \multicolumn{3}{|c|}{ 幅 $3 \sim 15$} & 5.30 & 5 & 24 & 5,305 & \begin{tabular}{l|l}
5 & 19.6
\end{tabular} & 14.5 & $|80.5|$ & 12 & 9.02 \\
\hline \multirow[b]{2}{*}{ 残 } & \multicolumn{3}{|c|}{ |残柱幅|過一㛚㟶柱数 } & & & & & & & & \multirow[b]{2}{*}{$\begin{array}{r}13.30 \\
9.15\end{array}$} & \multirow[b]{2}{*}{$\begin{array}{r}10.4 \\
7.1\end{array}$} \\
\hline & \begin{tabular}{|l|}
2 \\
2 \\
2
\end{tabular} & $\begin{array}{c}26 \\
8 \sim 10 \\
10\end{array}$ & $\begin{array}{l}2 \\
1 \\
2\end{array}$ & $\begin{array}{l}9.30 \\
5.50 \\
4\end{array}$ & $\begin{array}{l}12 \\
23 \\
22\end{array}$ & $\begin{array}{r}12 \\
6 \\
6\end{array}$ & $\begin{array}{l}8,550 \\
2,495 \\
1,895\end{array}$ & \begin{tabular}{c|c}
0 & 31.8 \\
5 & 9.3 \\
5 & 7
\end{tabular} & $\begin{array}{c}5.2 \\
12.5 \\
2\end{array}$ & $\begin{array}{l}82.8 \\
64.5 \\
76.0\end{array}$ & & \\
\hline \multirow{2}{*}{ 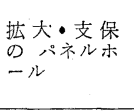 } & 支 保 & \multicolumn{2}{|c|}{ 幅 } & \multirow[b]{2}{*}{$\begin{array}{r}11 \\
7\end{array}$} & \multirow[b]{2}{*}{$\begin{array}{l}5 \\
5 \\
\end{array}$} & \multirow[b]{2}{*}{$\begin{array}{r}8 \\
18 \\
\end{array}$} & \multirow[b]{2}{*}{$\begin{array}{l}2,730 \\
6,003 \\
\end{array}$} & \multirow[b]{2}{*}{\begin{tabular}{l|l}
0 & 10.1 \\
3 & 22.2 \\
\end{tabular}} & \multirow[b]{2}{*}{$\begin{array}{c}21.9 \\
1\end{array}$} & \multirow[b]{2}{*}{$\begin{array}{l}73.1 \\
94.0 \\
\end{array}$} & \multirow[b]{2}{*}{$\begin{array}{r}6.25 \\
8.90 \\
\end{array}$} & \multirow[b]{2}{*}{4.85} \\
\hline & $\begin{array}{l}\text { 怘柱 } \\
\text { 空木精 } \\
\end{array}$ & 10 & & & & & & & & & & \\
\hline \multicolumn{4}{|c|}{1} & & & 74 & 26,978 & $8 \mid 100$ & & 81.0 & 10.79 & \begin{tabular}{|l|l}
9 & 7.96
\end{tabular} \\
\hline
\end{tabular}

第27·2表 稼 行 実緼

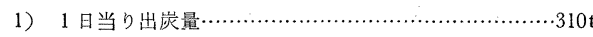

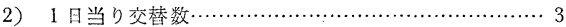

3） 1 日当り平均切羽進行量……...........................

4） 1 日当り実働工数…….....................................3

5）精炭生産 $1,000 \mathrm{t}$ 当り工数 $\cdots \cdots \cdots \cdots \cdots \cdots \cdots \cdots \cdots \cdots \cdots \cdots \cdots \cdots \cdots \cdots \cdots \cdots \cdots \cdots \cdots \cdots$

6）直接夫能率(O.M.S.) ……..........................

7）精炭 $\mathrm{t}$ 当り坑木消費量……............................. $5 \mathrm{dm}^{3}$ 


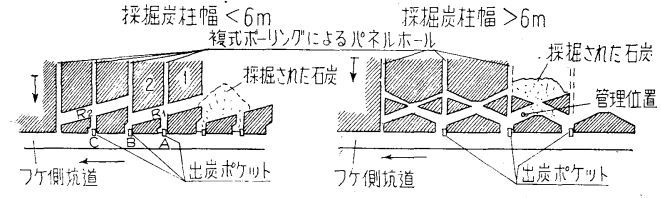

第27・1図 フケ侧の採準規格

玾道では，スプレー装置ならびに適宜なガイ装を施こ し，一方では炭壁注水を行なう。

通常, ウインチ側に 2 人, フケ側に 1 人，合計 3 人で 間に合い，3交替採炭を行なつた。

このようにして得た実績の要約が第 $27 \cdot 2$ 表である。設 備費は $\mathrm{t}$ 当り 0.60 フランで, そのらち0.35フランはボー リング関係で岁る。また動力や消耗資材等の経常費はト ン当り 2.50 フランで，ボーリング関係がそのなかの 1.33 フランを占める。かくして収益率は約 $200 \%$ になつた。

本試験は比較的良好な天盤状況に対してなされたもの であるが，現在は，種々の天盤状況に対しても応用調査 を続けている。

（黒岩忠春）

\section{8） Luisenthal 炭鉱の爆発について}

C. H. Fritzche und H. Schultze-Rhonhof : Das Explosionsungliick auf der Grube Luisenthal. (Glückauf, 101 (1965) 1, p. 23 33)

災害概況: 1962年 2 月 7 日午前 7 時50分にザールの Luisenthal 炭鉱のAlsbach 区でガス宸塵爆発が発生し，同 区内従業員664名中死者299名, 負賃者73名を生じた。災 害範囲に在つた 433名中 61名のみが全く無傷であつた。 死者の 5ち火傷扣よび外傷のみによる者 $159(53 \%)$ ，ガ ス中毒のみによる者 $99(33 \%)$ 抢よび火傷のみによる者 12(4\%) であつた。また 299 名中 286 名は坑内で死亡し た。災害当日151名が救出され, 残り 278 名の収容は数日 後までかかつた。

坑内条件: Luisenthal炭鉱は約4,600t/日で，炎害区域 Alsbach 区のそれは約 2,800 tであつた。稼行炭層は第 1 〜第 4 層まであり，揮発分 $35 \sim 39 \%$ の脂肪炭（ただし ルール地方の分類に従えばガス長炎炭に属す）で，層厚 $2 \sim 3 \mathrm{~m}$ ，傾斜 $15 \sim 20 \mathrm{~g}$ である。

主要区域は第 1 水準 (深度 $390 \mathrm{~m}$ ) と第 4 水潐（深度 $665 \mathrm{~m})$ の間にあり，昇向長壁式採掘を行ない水力充填 をして地表沈下を層厚の 25〜30\% 以内にとどめるよう にしていた。払長は $150 \sim 200 \mathrm{~m}$ で 1 切羽当り出炭は 600 800t/日，採炭にはカッタと発破が用いられた。ダ ブル切羽に対しては準備坑道が昇向に設けられ風道とさ れる。これは第 4 水準の走向開坑坑道己連絡される。

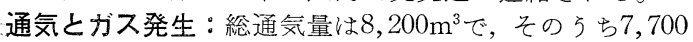
$\mathrm{m}^{3}$ が 3 分流に分けられて当区内に供給されていた。 Bochumの通気試験所の調査結果によれば有効風量率は 良好で，第 4 水準を経て掘進箇所へ供給される通気につ いても，抵抗扣よび通気圧は通気技術上普通の大きさで めつたが，一部の排気坑道には比較的断面積が狭く通気 負荷が大きいものがあつた。ただしこれが保安に重大な 影響を及活したわけではない。

Alsbach 区のガス発生量は出炭 $\mathrm{t}$ 当り $34 \mathrm{~m}^{3}$ でルール 地方の脂肪炭炭鉱の約 2 倍である。排気のガス含有率は $0.7 \pm 0.1 \%$ で, $41 \mathrm{~m}^{3} / \mathrm{t}\left(19 \mathrm{~m}^{3} / \mathrm{min}\right)$ は第 1 層の切羽から, $11 \mathrm{~m}^{3} / \mathrm{t}\left(15 \mathrm{~m}^{3} / \mathrm{min}\right)$ は第 3 層の切羽から発生していた。 このように第 1 層のガス発生は第 3 層のそれより多かつ :が，第 1 層の関係区域では爆発炎の作用は現われてい
ないので，この区域内のガス停滞は爆発の発生と伝ぱに 関係ないと認められた。第 3 層の切羽でも通気量が多く 風速も $1 \sim 1.5 \mathrm{~m} / \mathrm{s}$ 以下になることはないのでガス停滞 を生ずる危険は少なかつた。

苂害後のガス精密調查によると第 2 水準の立入坑道天 井下に相当の範囲にわたつてガスレーヤができているこ そがわかつた。これはその時まで炭鉱で使用していた安 全灯形検定灯では発見し難いものであつだ。しかも正 常通気時に天井矢木の裹には $5 \%$ を越えるガスのあるこ とがわかつた。また爆発前日に激しい大気圧降下があつ たので，爆発直前の天井ガスレーヤの範囲と量はかなり のものであつたと想像される。爆発前 6 時間の大気压降 下は水銀柱で $0.6 \mathrm{~mm} / \mathrm{h}$ ，前日 12 時間について $4 \mathrm{~mm} / \mathrm{h}$ で あつた。このほか地山運動によつてもガス湧出量の增加 することが知られている。

岩粉棚の効果: 当日この区域には38組の岩粉棚が設置し て山つた。このうち10䇫所で岩粉棚の効果により爆発伝 ぱが防止され，他の 4 箅所では風橋，湿つていて狭い坑 道，爆発波の相互衝突などの原因で伝ぱが停止した。他 の䈏所ではたとえ現在の法規で規定している通りの岩粉 棚を設けてあつても爆発伝ぱを防ぐことは不可能であつ たか子知れない。岩粉棚は多くの確認試験を経て定評が あり，かつ長い歴史を持つているが，決して爆発伝ぱ防 止の絶対最高の対策として信頼することはできない。

規定通りの岩粉棚が效果を発揮できない場合は次の二 つである。第 1 には岩粉棚を作動させる衝撃波と爆炎の 時間間隔が短かく，十分な岩粉雲が生成し難い場合でめ る。これは懪発性ガス混合気中に岩粉棚があり，岩粉棚 そ天井の間にガスレーヤがある時は特にその抏それが多 い。岩粉棚が効果を発揮するための衝撃波の限界は 500 $\mathrm{m} / \mathrm{s}$ までである。これ以上の爆速に対しては岩粉棚は無 効になる。しかもガスが広範囲に存在しているときガス 爆発が発生すればこの程度の爆速になることがある。第 2 には爆速が余り小さい時にも效果がない。例えば着火 地点付近㐫るいは, 爆心地から非常に遠い所では岩粉棚 が転倒しない。通常着火地点から $40 \sim 60 \mathrm{~m}$ 以内の岩粉 棚は無効である。その他爆発が坑道分岐点で分れた直後 などの場合も勢力が弱まり岩粉棚は作動されない。した がつて爆心地から 50〜100mの場合が最も有効である。

岩粉棚上の岩粉量も重大である。試験炭鉱の研究によ れば岩粉量が $70 \mathrm{~kg} / \mathrm{m}^{2}$ で伝ぱ防止ができることもあれば $400 \mathrm{~kg} / \mathrm{m}^{2}$ でも効果がないことがある。Loisenthal で伝 ぱ防止に成功した岩粉棚について当局が調查した結果で は岩粉量は法定の $400 \mathrm{~kg} / \mathrm{m}^{2}$ に足りなかつた。

岩粉棚の設置に関しては天井との間隔が短か過ぎるこ と，支保や圧気管に邪魔されていることなどで，岩粉の 飛散が妨害されるよらな事例があつた。しかしこれらが 爆発伝ぱ防止が不可能であつたことの主原因であつたと は考えられない。

炭塵爆発: 炭麼中の揮発分が多いものほど危険である が，必ずしも揮発分に比例するものではない。また粒度 は爆発強度に密接な関係が岁り，炭種により最適粒度が 異なるが脂肪炭拈よびがス長炎炭については $20 \sim 60 \mu$ が最も強い爆発をし $10 \mu$ 以下ではむしろ爆力は低下す る。試験炭鉱の試験によれば. Luisenthal 炭塵は非常に 爆発性が強く $1,100 \sim 1,700 \mathrm{~g} / \mathrm{m}^{3}$ で最大爆発をしている。

*.訳者注：ドイッでは日本の上うな舆気環を使用していないので安全 灯では天井下 $30 \mathrm{~cm}$ 以内のガ不検定はできない。 
炭塵爆発の証拠はコークス生成による。爆成球は浮遊 炭塵から，コークス層は支保面で生成し，しかもこれは 大抵は爆風進行方向の反対側に見出される。これは反動 作用によるもので，爆圧は前向ばかりでなく後向にも作 用するためである。例えば爆風によつて飛散された岩粉 棚は，反動により爆風方向の逆にも向５。しかし反動と 居り爆発とは区別すべきで，これは爆炎が消えた後に空 気が懪発区域へ逆流することによつて生ずるものであ る。Luisenthalでは坑内棈造が複雑で至る所で圧力平衡 が行なわれたため戻り爆発の存在は明らかには認められ なかつた。

爆源地と着火原因 爆風の進行方向, 破壊状況抢よびガ スの存在範囲から考光て爆源地の疑いある筃所が 3 つ つたが，そのうち第 2 水準の 221 号立入坑道の $3 \mathrm{~F}$ 目拔 の南西部が爆源地としての疑いが最も濃厚である。

着火原因については未だ最終結論に達していない。恐 らく着火原因についてめる種の情報を握つていたと思わ れる作業員は死亡してしまつた。諸々の検討の結果，電 気火花, 火炎, 坑内火災, 発破拉よび安全灯に関しては 全く問題はなかつた。爆源地と推定される範囲の数 $\mathrm{m}$ 外 側に煙草が発見されたが，爆発の状沅からこれが着火原 因ではないと推定された。ぬたその区域の 1 労働者のキ ヤップランプの保護ガラスと電球ガラスが破壞したと き，露出フイラメントが天井ガスレーヤに着火した可能 性も考えられたが，確定する根拠に乏しかつた。最も確 からしいるのは鋼製支保の降縮または折損による火花に よつてガスレーヤに着火してガス然焼を生じたと考えら れることである。

爆発の経過 爆発発生箇所の通気の余り良好でなかつた 立入坑道天井下にガスレーヤが生成して拈り，それが大 気圧の急激な降下で隹裂部からのガス湧出掞よび地山運 動によるガス発生によつて増強された後，ガス着火によ つてガス然焼を生じ，ガスレーヤの燃焙が伝ぱしている らちにガス爆発に到り, 坑内堆積炭歴を飛散させて炭塺 爆発を誘発し Alsbach 区内の全域にわたる大爆発にな つたと考えられる。この間一部の岩粉棚によつて伝ぱ防 止に成功した区域もあるが，岩粉棚がまつたく無効であ つた所も多かつた。

自己救命器の効果 当鉱は法規通り自己救命器を備えて いた。坑内の労働者中24名が多少のガス中毒を受けたが これにより命が助かつた。93例は自己救命器が役に立た なかつた。その理由の幾つかは着用が遅すぎたこと，跡 ガス中で喋つていたこと拉よび呼吸を楽にするため口片 をはずしたことにある。しかし大部分は酸素欠損と CO 濃度が非常に高かつたためでめる。Luisenthal 炎害後の 精密調査によれば $\mathrm{CO}$ マスクは $\mathrm{CO}$ が $1.5 \%$ 以上の場合 は適さないことが明らかにされた。CO 濃度が高いとき は発熱が高く，浄化された空気は数分以上吸入すること に耐えられない。Luisenthal 爆発の跡ガスは CO $2 \%$ 以 上の䇫所があつたと推定されている。

教訓たいていの大災害がそうであるように，当鉱の爆 発も多くの不幸な原因が重なつて, 爆発の発生と広範囲 にわたる伝ぱを生じた。すなわち, 通気不良坑道に採掘 の影響が及んだこと，採掘された炭層の $12 \mathrm{~m}$ 上に層厚 $2.5 \mathrm{~m}$ の炭層が露出していたこと，15 20 g の昇向採掘 をしていたこと, その運搬扣よび通気斜坑には水平坑道 のようには岩粉棚を設け難からたこと, 炭塵の爆発性が 強いこと, 坑道網が複雑なこと, 大気圧の急激な大降下
があつたこと，信頼できるガス検定器を十分に備えてい なかつたこと, 問題の区域に打ける CO 発生が CO マス クの能力以上であつたこと等である。

岩粉法の効果に関しては問題があるので, 新しく発達 しているペース法を岩粉散布の代りに用い，岩粉棚の代 りに水棚を用いることが坑内保安の向上に有益である。 炭塵堆積の激しい沿層坑道で炭層固着法を行なつていな い所では, 岩粉散布の効果に限りがあることを考慮して 岩粉棚の設置間隔を従来よりずつと短かくすべきであ. る。岩石坑道で炭塵堆積の少ないか, ほとんどない所で は，岩粉棚の間隔は従来通りでよい。

(房村信雄)

\section{選 鉱・選 炭}

\section{9）銅，ニッケルと閃覀鉛鉱粉末に対するザ ンセートとアルキル・トリメチル・アン モニウム・ブロマイドの等量溶液の吸着}

A. Pomianowski and J. Leja: Equimolar solutions of Xanthate and Alkyl Trimethyl Ammonium Bromide Adsorption on Copper, Nickel and Sphalerite Powders, (Trans. AIME. Soc. Mining Engineers Vol. 229, p. 307, 1964)

Bucknham そ Schulman 種々の捕収剂間の分子会 合を研究し, ザンセートとアルキル・トリメチル・アン モニゥム・ブロマイド $\left(\mathrm{C}_{n} \mathrm{~T} \mathrm{AB}\right)$ の混合物が，個々の鉱. 物の浮選に扮いて異常な協力作用を示すことを認めた。 本研究はこれらのことと関連して，次のようなことを目 的としてなされた。

1） 2 つの型の捕収剤間のこれらの分子会合が気液界 面に拈いてのみ打こるのか，あるいは，同様にバルク溶 液に拈いても抗こるのる確かめること。

2) 種々の固体が，両親媒性分子の混合物からいずれ かの種類を優先的に吸着するのか，あるいは分子錯体々 して吸着するのかを確かめること。

3）吸着の動力学に差があるかどうかを確かめること。 実 験 方 法

吸着実験装置 (第 $29 \cdot 1$ 図) は $210 \mathrm{~m} l$ の容器 $\mathrm{A}$, ガラス 管とTygon管，冷却コイルC，熔融ガラスの底 $(25 \sim 50$

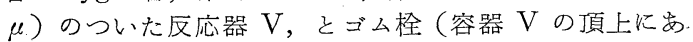
る）の下でフイルタを执さえている穴のあいた板からな つている。液流はガラス球のついた流量計を用いて 200 $\mathrm{m} l / \mathrm{min}$ に維持された。温度は $20^{\circ} \pm 1^{\circ} \mathrm{C}$ に保たれた。 充分洗浄され, 乾燥された装置に $200 \mathrm{~m} l$ の溶液と一定量 の粉末が加えられ，溶液は蠕動ポンプ (P) により 300 $\sim 600 \mathrm{~min}$ 循環された。その間， $1 / 4 \mathrm{ml}$ の試料が $1,3,6$, $10,18,30,60,100,180,300,600 \mathrm{~min}$ 後に分光光度法に上 る分析のためにとりだされた。紫外スペクトルが Perkin-Elmer 350 分光光度計で記録された。すべての試料 は 3〜 $5 \mathrm{~min}$ 以内に系にもどされた。吸着媒として用い られた固体粉末は Fisher Scientific Co. から入手した 純数な電解銅粉末, Sherritt Cordon Mines, Ltd から 大手したニッケル粉末と Broken. Hill 鉱山産の高純度. の閃亜鉛鉱粉末 $(-60+200 \mathrm{mesh})$ である。へキサン溶 液から脂肪酸の吸着によつて測定されたこれら粉末の比 表面積は $360 \sim 420 \mathrm{~cm}^{2} / \mathrm{g}$ であつた。

\section{実 験 結 果}

ザンセートと $\mathbf{C}_{n} \mathbf{T A B}$ の混合 : $10^{-4} \mathrm{M} \cdot \mathrm{KEtX}$ と $10^{-3}$ $\mathrm{C}_{12} \mathrm{TAB}$ 溶液のスペクトルの加成性が確められた。第 


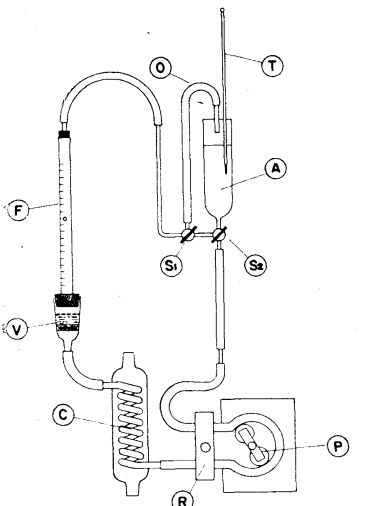

(A) $\leftarrow$ 第29・1図 昅収実験の ための循環装蜀

第29.3図 等モル濃度 $\rightarrow$ $\left(0.4 \times 10^{-3} \mathrm{M}, 1 \times 10^{-3}\right.$ M)の $\mathrm{C}_{12} \mathrm{TAB}$ が存 在する場合和よび存在 しない場合飞打ける $\mathrm{KEtX}$ の分解の動力学 ( ○は KEtX だけの溶 液, ・はKEtX と $\mathrm{C}_{12}$ $\mathrm{TAB}$ の当量混合液）

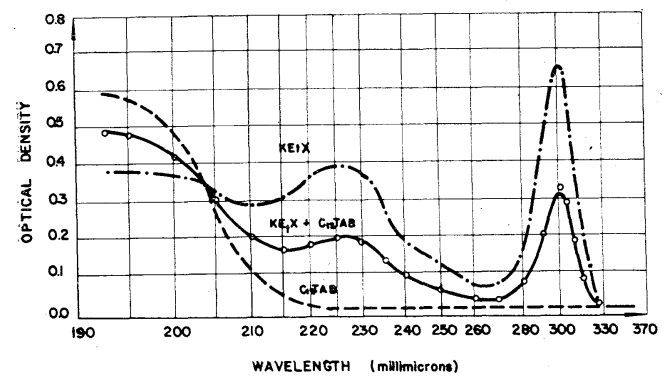

第29・2図 KEtX 抢よび $\mathrm{C}_{12} \mathrm{TAB}$ の紫外線スペクトルの加成 性 (点は加成值, 実線は湶合溶液のスペクトル)

29.2図に示されるように $301 \mathrm{~m} \mu て ゙$ 光学密度のわずかのず れは実験䛊差範囲内であると考えられる。しかし $10^{-3} \mathrm{M}$ ブチル・ザンセート・カリウムと $10^{-3} \mathrm{MC}_{12} \mathrm{TAB}$ の混 合物に対して, $215 \mathrm{~m} \mu$ より短い波長での光学密度は加 成性から計算されるよりも高く，また，ヘキシル・ザンセ ート・カリウム々の混合物は 2 成分の混合後直ちに強い 乳光を呈し,さらに強い光学密度を示した。ノニル・ザ ンセート・カリウムとの混合は直ちに沈殿物を生じた。 沈殿物を沪過あるいは遠心分離後の溶液のスペクトルは 原液の $3 \%$ のザンセートしか示さなかつた。しかし，溶 液に残存している $\mathrm{C}_{12} \mathrm{TAB}$ 濃度は沈殿の除去によつて 影響されなかつた。

$\mathrm{KEtX}$ 溶液の安定性が $\mathrm{pH} \fallingdotseq 6$, 温度 $22^{\circ} \pm 3^{\circ} \mathrm{C}$ デテト されたが，ザンセートの分解は一次反応であり， $\mathrm{C}_{12} \mathrm{~T}$ $\mathrm{AB}$ の存否に無関係で, その半減期は $29 \pm 3$ 日であるこ とがわかつた(第29・3図)。

銅とニッケル粉末に対するザンセート吸着試験 : $200 \mathrm{~m} l$ の $10^{-3} \mathrm{M} \cdot \mathrm{KEtX}$ 溶液がそれぞれ $1.8 \mathrm{~g}$ の銅粉末と $30 \mathrm{~g}$ の ニッケル粉末を通して循環させられた。固体 $1 \mathrm{~g}$ 当りの 吸着量は

$$
\Gamma=\left(C_{0}-C_{t}\right) / W \quad \mu \mathrm{mol} / \mathrm{g}
$$

として計算された。ここに $C_{0}$ は初濃度, $C_{t}$ は $t \min$ 後の 濃度，Wは使用された固体の重量である。 $\log \Gamma$ と $\log t$ の 関係が第 $29 \cdot 4$ 図に示される。銅粉末によるザンセートの 吸着は最初の 2 3min でも非常に大であるが, 約 $30 \mathrm{~min}$ 後にはその速度は滅少してくる。 $\mathrm{KEtX}$ のみ含む場 合, $>20 \mathrm{~min}$ において $\Gamma=K^{\prime} \cdot t^{0.22}, \mathrm{KEtX}$ と $\mathrm{C}_{12} \mathrm{TAB}$ の当量混合物に対しては $>30 \mathrm{~min} に$ 打いて $\Gamma=K^{\prime \prime} \cdot t^{0.16}$ の直線関係が見られる。ニッケルによる吸着量は銅によ るそれよりも約 $1 / 10$ であり吸着の動力学は明らかに異な
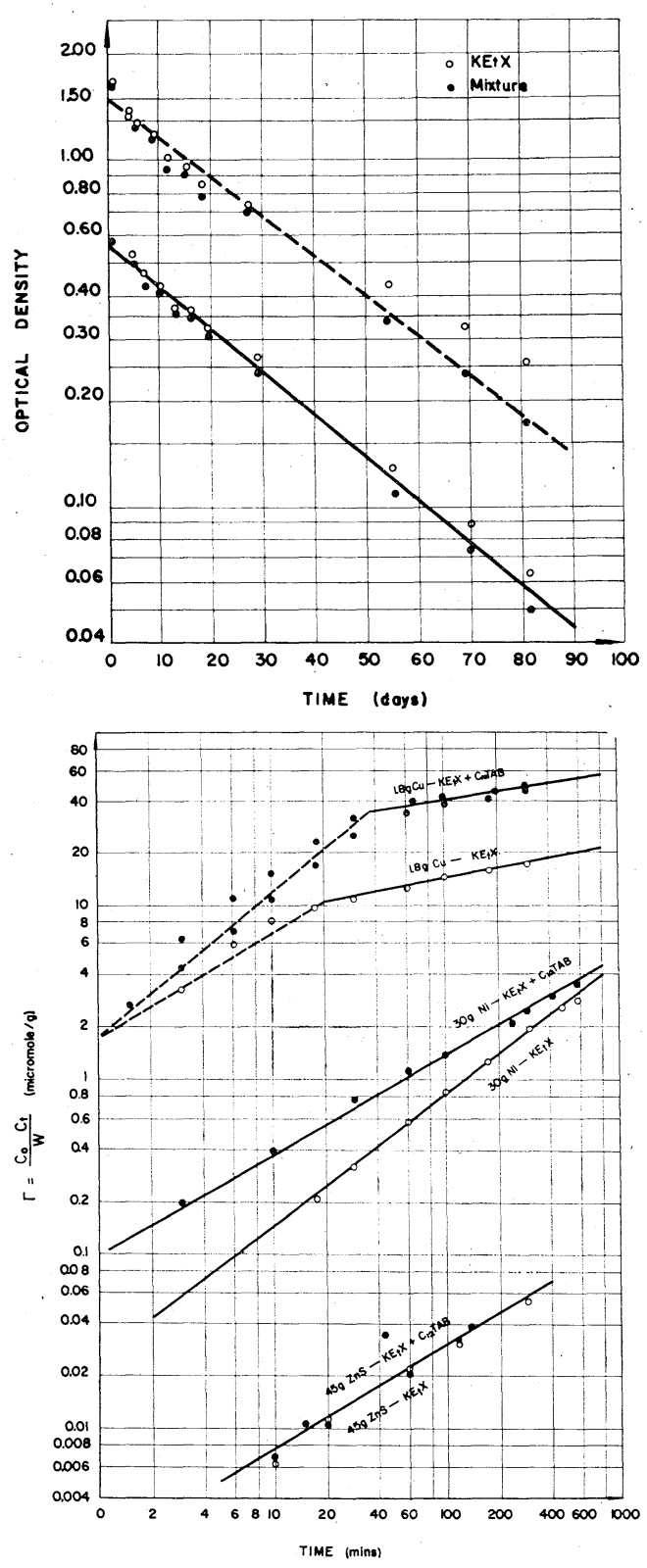

第29・4図 銅, ニッケルおよび閃亜銓鉱粉末に対するエチルザン セートイオンの吸着の動力学

つている。ニッケルに対する直線からKEtXのみの場合 には $\Gamma=K_{1} \cdot t^{0.7}, \mathrm{KEtX}-\mathrm{C}_{12} \mathrm{TAB}$ 溶液に 対しては $\Gamma=$ $K_{2} \cdot t^{0.57}$ である。使用された各粉末に対しては $\mathrm{KEtX}$ と $\mathrm{C}_{12} \mathrm{TAB}$ の当量混合物からの $\mathrm{KEtX}$ の吸着量は $\mathrm{KEtX}$ のみの場合よりも大である。

閃亜鉛鉱粉末に対するザンセート吸着試験：予備実験の

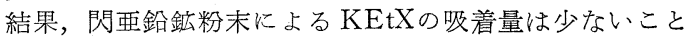
がわかつたので，40〜 50 g の閃亜鉛鉣粉末に対し $10^{-5} \mathrm{M}$ ザンセート溶液で試験した。得られた結果を銅とニッケ ルの堭合と比較して第 29.4 図に示す。この場合, $\Gamma=$ $0.002 t^{0.58}$ の関係がみられた。

考察 
$\mathrm{KEtX}$ と $\mathrm{C}_{12} \mathrm{TAB}$ の混合物に対する分光光度的結果 は存在する吸収帯の移動と新しい吸収带が得られないの で，特殊な錯体は形成されない。しかし，長鎖ザンセ一 トと $\mathrm{C}_{n} \mathrm{TAB}$ の混合物の乳濁と沈殿効果はある相互作 用が強くおこることを示している。この反応は 2 つの反 対に荷電された種属の共沈というよりも長鎖ザンセート が選択的に沈殿するということは注目されるべきであ る。また伝導度の測定結果から，ザンセートと $\mathrm{C}_{n} \mathrm{TAB}$ の分子会合が気一液界面に打けると同様にバルク溶液に 扣いて抗こることが推論された。

第 2 の目的，すなわち，吸着が選択的であるか否か は，ザンセートが優先的に銅とニッケルに吸着し，閃亜 鉛鉱粉末に対しては吸着しないということを結果が示し ている。これらの 3 つのタイプの粉末に対するすべての 実験に打いて $\mathrm{C}_{12} \mathrm{TAB}$ の吸着は注とんど単分子層程度で あつたが、ニッケル粉末によるザンセートの吸着は 600 $\min$ 後では10々15分子層（それぞれ $\mathrm{KEtX}$ のみの場合と $\mathrm{C}_{12} \mathrm{TAB}$ の混合物の場合）であり，銅粉末によるザンセ 一トの吸着は $300 \mathrm{~min}$ 後でそれぞれ 60 と 200 分子層であつ て，これらの両試料に対しては，溶液中の $\mathrm{C}_{12} \mathrm{TAB} の$ 存在は $\mathrm{KEtX}$ の優先的な吸着を強力に增加した。しか し， $\mathrm{C}_{12} \mathrm{TAB}$ 存在は閃两鉛鉱によつて吸着されたほぼ 単分子層のザンセート量に著しい影響を与えなかつた。

また，銅粉末に対して $\mathrm{C}_{12} \mathrm{TAB}$ が存在する場合も， しない場合も20〜30 min 後に $\mathrm{KEtX}$ の吸着の速度に 急激な変化が見られるが、ニッケルや閃亜鉛鉱にはこの 傾向は認められない。

以上の結果からは，ザンセート吸着の精確な機構は評 価され得ないが，銅によるザンセートの吸着速度の突然 の変化は，多分子吸着層の突然の変化を示しているもの と思われる。Plaksin らによつて得られたオートラジオ グラフィーの結果と対応して, 著者らは, 不均一に分布 されたザンセートの多分子層の微結晶が連続的に緻密な 被膜を形成するまで，これらの微結晶が，反応体*の固 体への，また固体からの拡散を妨害しないということを 仮定する。すなわち，そのような被膜の成長は，銅の場 合には反応速度を低めるように突然変化することによつ て示されるが，ニッケルや閃亚鉛鉱粉末にはこのような ことは認められない。

(松岡 功)

\section{0）蒸気を利用した汇過における脱水の機構}

J. H. BRown: The Mechanism of Dewatering by Steam Filtration. (The Canadian Mining and Metallurgical Bulletin, March 1965, p. 315-319)

蒸気を利用した沪過では，沪過過程で過熱蒸気をケー ク中に通して脱水を行ならが，その脱水の機構につい て，石炭拉よび鉄鉱石による基礎試験扣よび中間試験を 行なつた。

装置および方法：実験に使用した回分式フィルターを 第30・1図に示す。原則として蒸気は大気圧でケーク面に

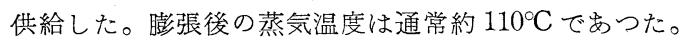
蒸気の膨張によるケークの観乱を防ぐためにバッフルプ レートが必要であつた。

* 固体によるザンセートの吸着は，溶液中に存在し，ぬた固体表面上 に酸化生成物として存在する酸素, ザンセートイオン, 金属イオン およびヂキサントゲンの複雑な反応である。
第30・1表 試料の粒度分布

\begin{tabular}{|c|c|c|c|c|c|c|c|c|c|c|c|c|}
\hline \multirow{2}{*}{ 試料 } & \multicolumn{12}{|c|}{ 通 過 分 積 算 重 量 \% } \\
\hline & $3 \mathrm{M}$ & $6 \mathrm{M}$ & $10 \mathrm{M}$ & $20 \mathrm{M}$ & $28 \mathrm{M}$ & $35 \mathrm{M}$ & {$[48 \mathrm{M}$} & $165 \mathrm{M}$ & $100 \mathrm{M}$ & $150 \mathrm{M}$ & $200 \mathrm{M}$ & $325 \mathrm{M}$ \\
\hline 鉄精鍼 & - & - & 99.9 & 80.2 & - & 40.3 & - & 13.5 & 6.8 . & - & 1.0 & - \\
\hline 石崖A & $\begin{array}{r}0 \\
89.3\end{array}$ & $\begin{array}{l}77.0 \\
64.0\end{array}$ & - & $=$ & $\mid \begin{array}{l}23.0 \\
20.4\end{array}$ & - & $\bar{z}$ & - & - & 9.5 & $\begin{array}{l}4.5 \\
6.0\end{array}$ & $\begin{array}{l}2.9 \\
5.4\end{array}$ \\
\hline C & - & - & - & $-?$ & 99.9 & - & 65.9 & 950.6 & 37.5 & - & 21.8 & - \\
\hline D & - & - & - & - & - & - & - & 100 & 74.1 & - & 43.1 & - \\
\hline $\mathrm{E}$ & - & - & - & - & - & - & 94.0 & 87.0 & 76.5 & 63.0 & 51.5 & 43.0 \\
\hline $\mathrm{F}$ & - & - & - & - & - & - & - & - & 97.5 & 87.0 & 78.0 & 66.0 \\
\hline
\end{tabular}

各試験ともフィードは，操業フィルタのフィードに近 いスラリーとした。主としてサンプリング間の水分の蒸 発のため，産物水分のよい再現性を得ることは困難であ つたが，低水分の鉄精鉱では0.25\%以内の再現性を示し た。第30・1表に実験に使用した試料の粒度分布を示す。

実験結果：第30.2図は広い粒度分布をもつ石炭を蒸気 沪過で処理できることを示して扣りこれから蒸気を通 した後の残留水分は粒度分布に影響されることがわか る。なた，泠却した産物の水分がさらに下るのは，蒸発 によるものである。

ケーク内温度（第30・1困の熱電対 2 にる測定）は， 蒸気の通気時間の関数である(第30.3図)。鉄精鉱ではB の曲線と汪とんど同じであつた。ケーク温度が $77^{\circ} \mathrm{CW上}$ になると脱水効果は著しいことはわかつたが，温度と水 分のはつきりした相関関係はつかめなかつた。

第30・4区は種々のケーク厚さおよび真空度における鉄 精鉱ケークの脱水の進行状況を示したもので，透過性の よいケークでは，秒の単位で $1 \%$ 以下の水分になる。従 来の沪過では，数分間で $3.5 \%$ 程度の水分になるにすぎ ない。

試験に使用したマノメータは,蒸気沪過における打力 変化を詳細に記録するには充分でなかつたがケケー下 の圧力は，第30.5図に示すように時間の経過とともに， 最大值をへて降下することがわかつた。この変化は同一 の装置を用いて行なつた普通の沪過の場合には見られな い現象であつた。

鉄精鉱についてて間試験を行ない，第30.3区，第30.4 図に示された曲線傾向を確認し，脱水効果および加熱限

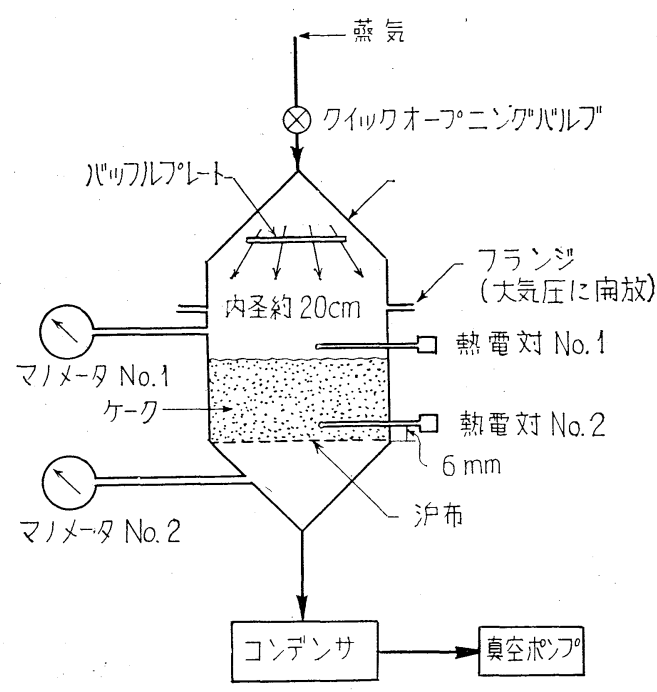

第30.1図 実験に使用した回分式フイルタ 
第30.2表ヶ一クの脱水に必要な熱量

\begin{tabular}{|c|c|c|c|c|c|}
\hline \multicolumn{3}{|c|}{ 蒸気として脱水する場合（普通の加熱乾燥） } & \multicolumn{3}{|c|}{ 液として脱水する場 合（蒸気沪過） } \\
\hline (1) & 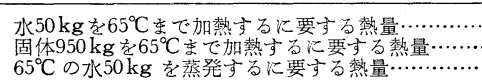 & $\begin{array}{l}\ldots .300 \mathrm{kcal} \\
11,400 \mathrm{kcal} \\
.12,200 \mathrm{kcal}\end{array}$ & (1) & 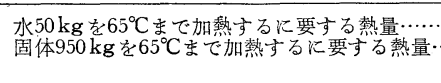 & , \\
\hline & 計 & $23,900 \mathrm{kcal}$ & & & $11,700 \mathrm{kcal}$ \\
\hline
\end{tabular}

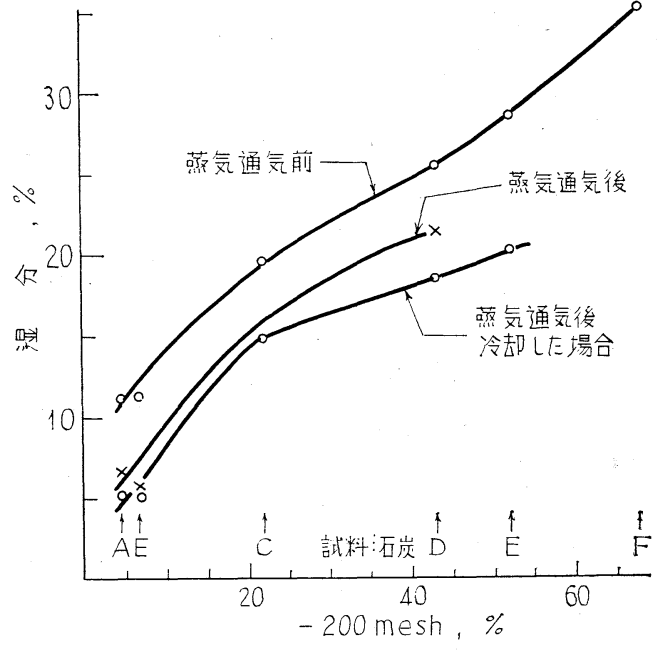

第30・2図 -200 meshの量と，石炭ケーク水分との関係

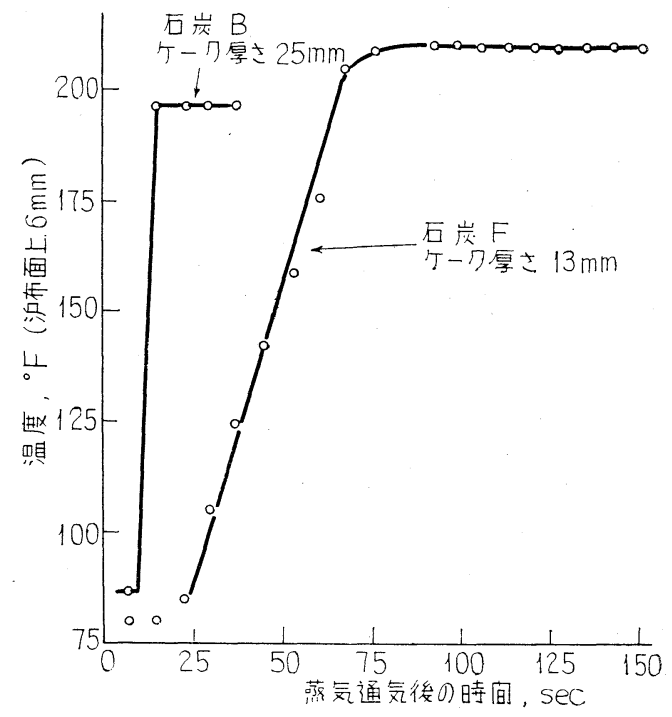

第30・3図蒸気通気時間とケーク内温度との関係

界をはつきりつかむことができた。石炭に関する中間試 験では蒸気流の測定を行なつた。比較的薄いケークで行 なつたため蒸気口スがあつたが，蒸気消費量は単にケー クを加熱するに要する量の 2 倍以下であることがわから た。

考察 : 蒸気沪過では,ケーク中に第30・6図に示すよう な 4 つのゾーンが形成される。蒸気はケークに入ると， ケーク頂部(表面にもつとも近い部分)で多量の熱を失な

$652\langle 64\rangle$

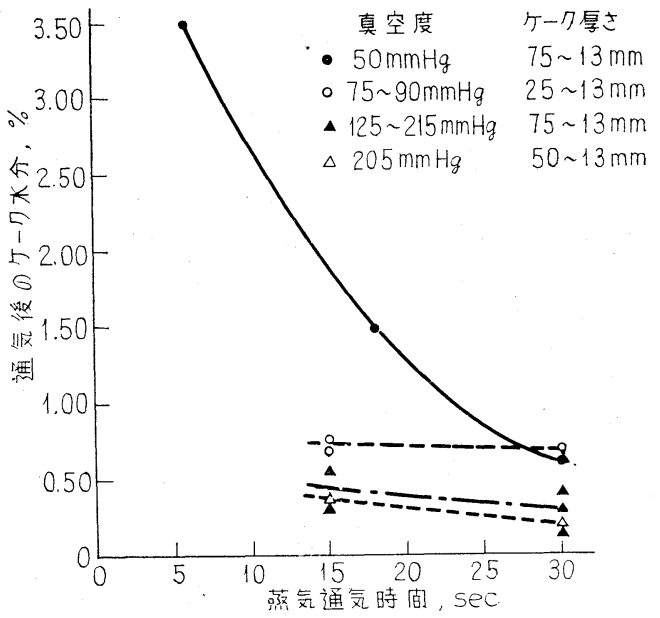

第30.4図 蒸気通気時間と水分の関係（鉄精鉣）

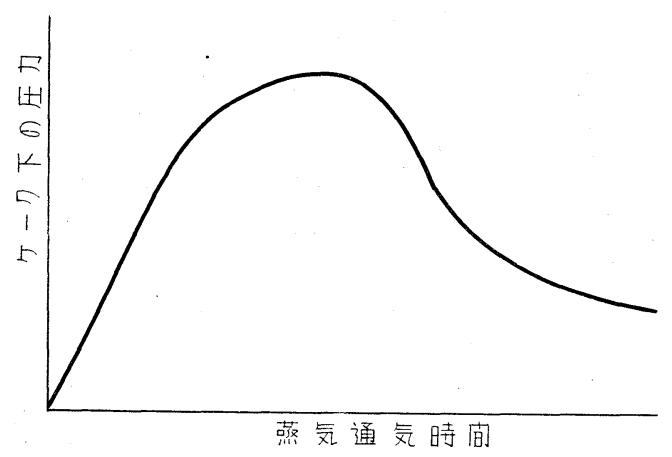

第30・5図蒸気通気時間とケーク下の任力

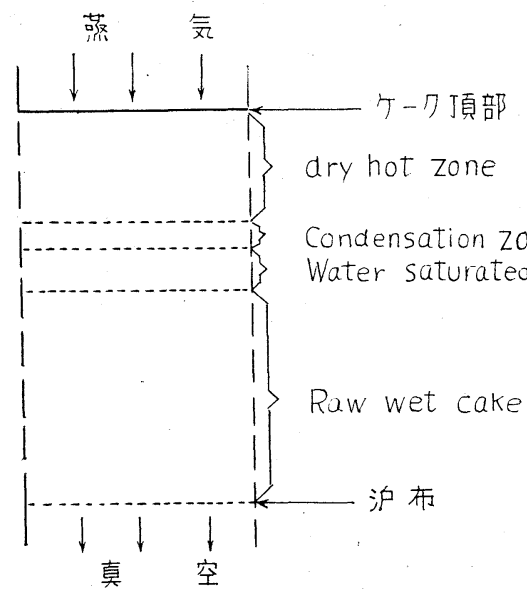

第30.6図 ケーク内の 4 つのゾーンの形成 
5（乾熱帯-dry hot zone)。次の凝縮帯 (condensation zone）に達すると，蒸気は凝縮し潜熱を放出する。この 潜熱はケークおよび含有水分の温度を高める。温度上昇 により水の粘性が低下するため，急速に脱水され，次の ゾーンの粒子間吵を飽和する（飽和水带-water-saturateed zone)。飽和水帯では脱水された水分は冷たいケ一 クに触れて冷却される。したがつて，ケークを通過する 冷水流が蒸気沪過に扣ける律速因子と考兄られる。第 30・3図に示された急激な温度上昇は潜熱の放出による結 果であり, 曲線 $\mathrm{B}, \mathrm{F}$ の違いはケーク層の透過性の差によ り熱伝達速度が異なることに基くものである。

ケークの最終水分は,ケークの水分保持能力 (moisture-retention capacity) によつてきまるから，粒子の細 かさに関係する。この能力はケークの空隙率, 接触角拈 よび液の表面張力によつてきまり，これらは沸点までは 水分の温度上昇により急激に変化しない。しかし温度上 昇により水の粘性は低下し, 凝縮带から急速に脱水され る。

ケーク内の加熱水分の急激な脱水により，飽和水带が 形成され，そのために第30.5図に示した圧力降下が現わ れるものと考えられる。

蒸気沪過プロセスの最も重要な特徴は, 水分がケーク から蒸気としてではなく水として除去されることであ る。したがつて飽和水帯の水が除去された後まで蒸気を 通すことは意味がない。すなわちケークを加熱するに充 分な蒸気のみでよいことになる。

蒸気沪過に必要な熱は大部分潜熱であるから，蒸気を あらかじめ高温にしておく必要はない。実際には約 120 ${ }^{\circ} \mathrm{C}$ で使用されよう。

ケークを加熱乾燥した場合と蒸気汇過により脱水した 場合の必要熱量の差を第 $30 \cdot 2$ 表に示す。

第 $30 \cdot 2$ 表の例で，原料 $1 \mathrm{t}$ 女たりの必要蒸気量は約 36 $\mathrm{kg}$ と推定できる。

(野中道郎)

\section{冶金}

\section{1）硫酸銅と塩基性硫酸銅の熱分解の速度論}

T. R. Ingraham and P. Marier: Kinetics of the Thermal Decomposition of Cupric Sulfate and Cupric Oxysulfate(Trans. Met. Soc. AIME 233, 363-67, 1965)

$\mathrm{CuSO}_{4}$ が熱分解して $\mathrm{CuO}$ に成る中間段階に $\mathrm{CuSO}_{4}$ • $\mathrm{CuO}$ がある。ここでは $\mathrm{CuSO}_{4}, \mathrm{CuSO}_{4} \cdot \mathrm{CuO}$ の熱 分解反応を速度論的にとりめつかい反応界面面積の変 化，ガス流量，扣よびその中の $\mathrm{SO}_{3}$ 分圧等が分解速度 に及ぼす影響から，分解反応の機粗の解明が行なわれ た。

実験に使用した $\mathrm{CuSO}_{4}$ および $\mathrm{CuSO}_{4} ・ \mathrm{CuO}$ は前 報*そ同様のもので，これを $7 \mathrm{t} / \mathrm{cm}^{2}$ でコンパクトなペ レットにした。ペレットは高さ扰よび直径. $0.625 \mathrm{~cm}$ そ高さ $0.059 \mathrm{~cm}$, 直径 $1.25 \mathrm{~cm}$ の二種類の大きさが使用 された。ペレットは AMINCO 熱天科中で，分解圧よ りわずかに高い $\mathrm{SO}_{3}$ 分王を持つた $\mathrm{N}_{2}$ ガスを流して加 熱され，それが分解温度に達したところで所定の $\mathrm{SO}_{3}$ 分

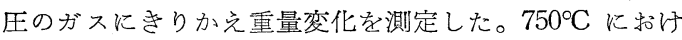

* T. R. Ingraham. "Thermodynamics of the Thermal Decomposition of Cupric Sulfate and Cupric Oxysulfate". Trans. Metall. Soc. AIME 233 359-63(1965)

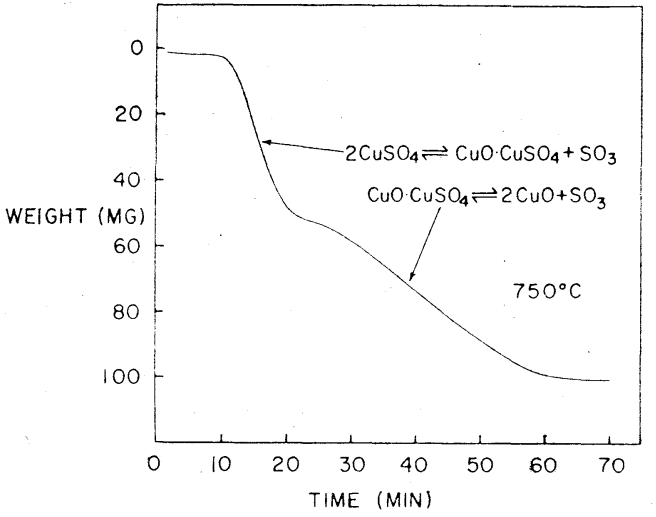

第31・1図 熱 分 解 曲 線

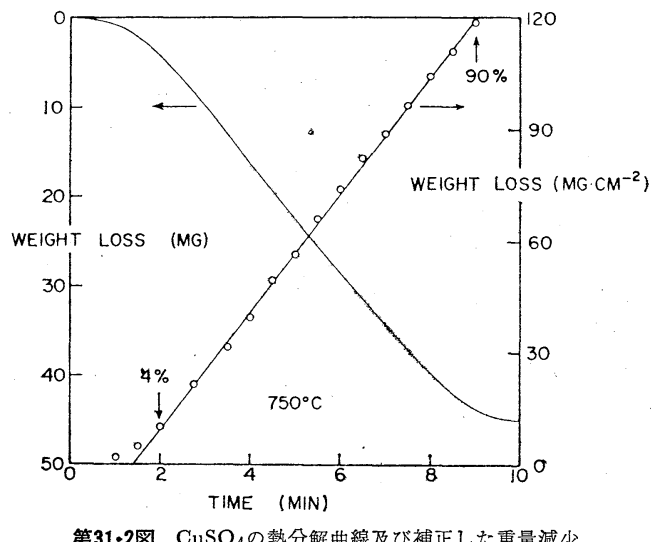

第31・2図 $\mathrm{CuSO}_{4}$ の熱分解曲線及び補正した重量減少

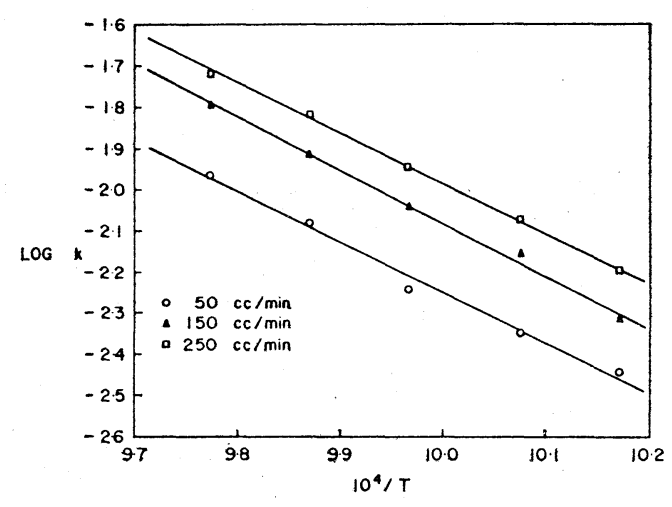

第31·3図 アレニウスプロット

る $\mathrm{CuSO}_{4}$ の分解の減量率一時間曲線（第31・1図）から $\mathrm{CuSO}_{4}$ の分解は, $2 \mathrm{CuSO}_{4} \rightarrow \mathrm{CuSO}_{4} \cdot \mathrm{CuO}+\mathrm{SO}_{3}$ と $\mathrm{Cu}$ $\mathrm{SO}_{4} \cdot \mathrm{CuO} \rightarrow 2 \mathrm{CuO}+\mathrm{SO}_{3}$ の 2 段に起つていることがわ かる。1段目の反応速度の研究には $\mathrm{CuSO}_{4}$ の，2段目 には $\mathrm{CuSO}_{4} \cdot \mathrm{CuO}$ のペレットが使用された。ペレット がコンパクトな場合, 固体から気体と固体が生成する分 解反応は表面から起り, 一定温度では, 一定速度で内側 に向つて進行する。このとき反応物と生成物の間の界面 は非常にはつきりしている。それ故, $\mathrm{CuSO}_{4}$ の第 1 段 目の反応の測定值は典型的な sigmoid 型で，これを分 


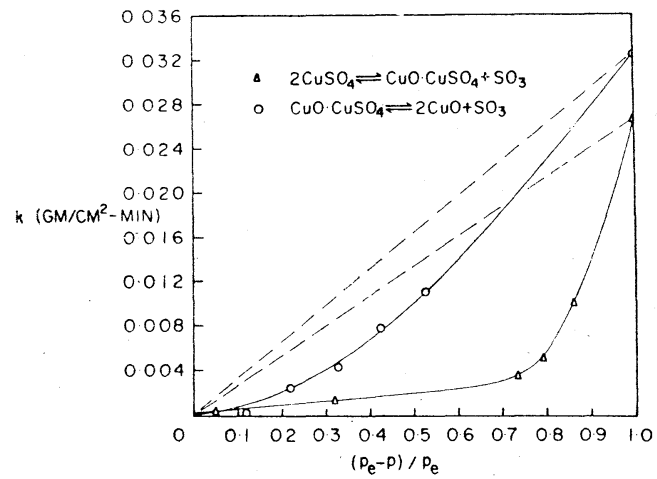

第31.4図 分解速度と $p_{e} p / p_{e}$ の関倸

解の進行と共に変化する界面面積の関数として表わし, 界面単位面積から去つて行く $\mathrm{SO}_{3}$ の重量に換算すると 分解率 4 90\%の間で淔線となり，分解反忘は零次であ ることがわかる(第31・2図)。

種々の温度およびガス流量での実験結果をアレニウス プロットした(第31・3図)。50〜2,000 cc/min までガス流 量を変化させたが反応が流量に影響されないよ5な範用 は得られなかつた。また，各ガス流量に拈ける分解反応 のアレニウスプロットが平行でめることから $\Delta Q$ は一定 と考光られる。第 $31 \cdot 3$ 祖から求めた $\mathrm{CuSO}_{4}$ の分解の活 性化エネルギーは $57 \pm 7 \mathrm{kcal} / \mathrm{mol}$ ，同様な実験から求め た $\mathrm{CuSO}_{4} \cdot \mathrm{CuO}$ のそれは $67 \pm 8 \mathrm{kcal} / \mathrm{mol}$ であつた。

$\mathrm{SO}_{3}$ を含んだ $\mathrm{N}_{2}$ めるいは $\mathrm{Ar}$ 気流中での実験で得 た分解速度を $\left(p_{e}-p\right) / p$ に対してプロットした（第31.4 図)。ただし $p_{e}$ は分解の平衡王， $p$ はそのときのガス流 中の $\mathrm{SO}_{3}$ 分王である)。不均質系の分解反応速度が ( $p_{e}$ -p)/ $p_{e}$ に比例する例が多く知られているが，この実験 では比例関係から大きく偏奇した。偏奇の原因之して， ガス流中のわずかな $\mathrm{SO}_{3}$ 分圧で分解速度が大きく変る ことから, Langmuin の吸着等温式に従う吸着現象を想 定した。

反応界面の $5 ち \mathrm{SO}_{3}$ が吸着している割合を $\theta$ とする 子

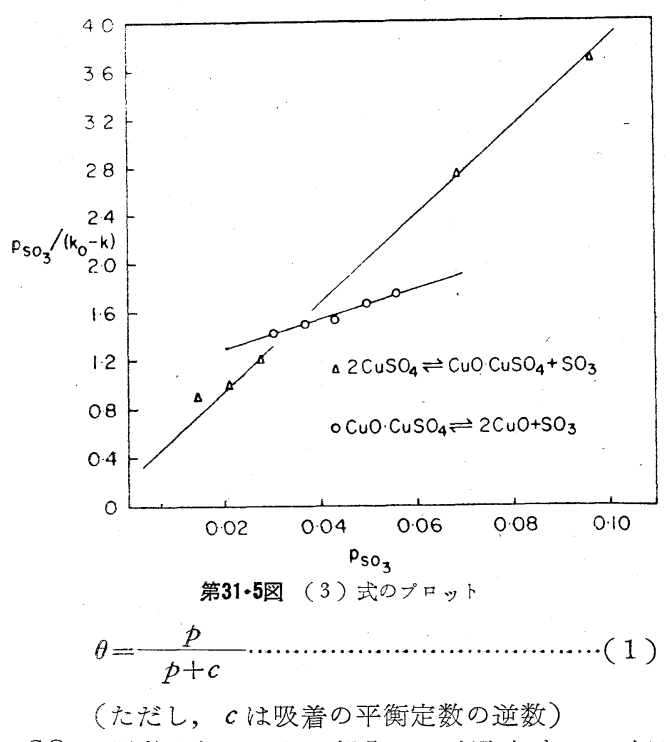

$\mathrm{SO}_{3}$ で吸着されていない部分のみが反応すると仮定 乙， $\theta=1$ のとき速度定数 $k=0, \theta=0$ のとき $k=k_{0}$, ここで $k_{0}$ 法測定される最大の速度定数とする。この仮 定から

$$
\theta=\frac{k_{0}-k}{k}
$$

(1)，(2) 式から

$$
\frac{p}{k_{0}-k}=\frac{p}{k_{0}}+\frac{c}{k_{0}}
$$

この式に測定結果を代入して，p をプロットすると直線に成り前の仮定が成立することが わかつた。以上の結果から，分解反応速度は上で想定し たように，反応界面に护唇 $\mathrm{CuSO}_{4}$ の中， $\mathrm{SO}_{3}$ を吸 着していないるのを $\left(\mathrm{CuSO}_{4}\right)$ active とすると rate $\propto\left(\mathrm{CuSO}_{4}\right)$ active $\propto(1-\theta)$

でありこの $\theta$ はペレット表面の $p_{\mathrm{SO}_{3}}$ でュントロール されるものである。 $\mathrm{CuSO}_{4} \cdot \mathrm{CuO}$ についてもまつたく 同様である。

(木内弘道) 